\title{
Glycemic Index and Insulin Index of Palmyrah Based Edible Products Commonly Consumed in Jaffna
}

\author{
S. Mahilrajan ${ }^{1}$, S. Balakumar ${ }^{2}$, V. Arasaratnam ${ }^{2}$, T. Kumanan ${ }^{3}$ and R. \\ Kailayalinkam ${ }^{1}$ \\ ${ }^{I}$ Palmyrah Research Institute, Kandy Road, Kaithady, Jaffna, Sri Lanka \\ ${ }^{2}$ Department of Biochemistry, Faculty of Medicine, University of Jaffna, Sri Lanka \\ ${ }^{3}$ Department of Medicine, Faculty of Medicine, University of Jaffna, Sri Lanka
}

\begin{abstract}
The objective of this study was to determine the insulin index and glucose index to isoenergetic (1000-kJ) portions of palmyrah based foods commonly consumed in Jaffna and their correlations between nutrient and phytochemical contents. Subjects were selected those having fasting blood sugar less than 100 $\mathrm{mg} / \mathrm{dl}$. Glucose (reference food) and four test foods such as pinnatu, Jaggery, odiyalpittu and pullukodiyal flour snak were administrated to four groups of 24 subjects and serving weight were calculated based on the energy content. Subjects were fasted forl2h before the administration of foods then venous blood samples were collected at 0 time and every 30 min for two hours after either feeding with glucose and test foods. An insulin score and glycemic score were calculated from the area under the insulin/glucose response curve for each food with the use of reference food. Among the test foods pinattu has low glycemic (52.9\%) and low insulin index (36.47\%).Carbohydrate, ash and Total Dietary Fiber (TDF) present in the those products were negatively correlated with glycemic index. Insulin index was negatively correlated with TDF, protein and ash contents. Not only the nutrient contents but also the phytochemicals such as total phenols and flavonoids showed negative correlation. All the tested products showed less plasma insulin, although high plasma insulin causes coronary heart disease. Therefore palmyrah products could be used in order to develop new value added foods, which could have more beneficial health properties regarding glucose and insulin metabolism.
\end{abstract}

Keywords: Insulin, glycemic index, carbohydrate and total dietary fiber

\section{Introduction}

Palmyrah palm has great economic potential and every part of the palm has economic value [1]. The edible palm products are classified into sap, fruit and tuber based products. Among the sap based products 'neera' is obtained by tapping the inflorescences, which is consumed as such after deliming process or converted in to jaggery, sugar or candy [2]. Ripped fruit pulp used in different food preparations at domestic level. Fresh palmyrah pulp could be extracted manually or mechanically [3]. The fibers are removed by straining through muslin cloths sunlightdried by called 'pinnatu'. Tuber based products such as palmyrah 'odiyal flour' (dried tuber flour) and 'plukodiyal flour' (boiled, dried tuber flour) are used for traditional food preparations. Palmyrahfruit pulp has shown antidiabetic [4], anti-inflammatory [5], wound healing, anthelmintic activity [6], analgesic and antipyretic activity [5]. Methanolic extract of the male flowers of Borassus flabelliferinhibited the serum glucose levels in sucrose-loaded rats, which may be due to presence of spirostane-type steroid saponins [7]. It also has been documented that palmyrah flour possesses immunosuppressant property [8]. Even though the palmyrah has innumerable medical importance [9] it has not received due importance.

Among the palmyrah-based products, fruit pulp showed caloric value (energy) is $102.83 \mathrm{kcal} / 100 \mathrm{~g}$ [10] and also contained more than 5\% of soluble fiber [11], which may influence on glycemic and insulinemic response [4]. Lu et al., (2004) [12] have shown that ingestion of arabinoxylan rich fibers decreased postprandial insulin and glucose responses in healthy subjects. Chandalia et al., (2000) [13] have shown that a high dose intake of fibers over six weeks had beneficial effects on type 2 diabetes patients by improving glycaemic control, attenuating hyper insulinaemia. Even though the palmyrah food based edible products are the traditional foods of Jaffna inhabitants, their nutritive values have not been studied so far.The aim of this study was to determine the postprandial insulin responses and glucose response to isoenergetic portions of palmyrah based products such as Jaggery, pinattu, odiyalpittu and pullukodiyalflour snak in non-diabetic subjects.

\subsection{Materials}

\section{Material And Methods}

Glucose (Glucolin pure glucose) was from SmithKline Beecham (Pvt) Ltd, Colombo-01. 'Pinattu', 'odiyal' flour and 'pullukodiyal' flour were from 'Katpaham' Sale Center, Palmyrah Development Board, Jaffna, Sri Lanka and the 'Jaggery' was from Pandatharippu Palm Development Society Jaffna, Sri Lanka. 


\subsection{Preparation of test foods}

The foods were selected to represent palmyrah based natural and processed foods commonly consumed in Jaffna peninsula populates. Foods were prepared in bulk to minimize variations in composition. Each food was served as a $1000 \mathrm{~kJ}$ portion with $250 \mathrm{~mL}$ water.

'Pinattu'

Pinattu cut in to $2.0 \times 1.0 \times 0.3 \mathrm{~cm}^{3}$ slabs was used.

'Odiyal pittu'

The odiyal flour $(250 \mathrm{~g})$ was soaked in $2500 \mathrm{ml}$ water for 60 minutes, strained through a muslin cloth and squeezed to wet dry. After mixing with wheat flour $(50 \mathrm{~g})$ and salt the mixture which was made into fine granules, mixed with scrapped coconut $(75 \mathrm{~g})$ and steamed for 20 minutes.

'Pullukodiyal' floursnak

'Pullukodiyal' flour $(200 \mathrm{~g})$ was mixed with sugar $(20 \mathrm{~g})$, scrapped coconut $(50 \mathrm{~g})$ and water $(100 \mathrm{ml})$ and made into small balls.

\subsection{Analytical method}

Determination of energy contents of the Palmyra based foods

The energy content of each of the food preparations were measured with Bomb Calorimeter (e2k) and serving weight was calculated for each food is have a total energy of 1000kJ [14].

Nutrient analysis

All the food samples were analyzed for moisture, fat, protein, ash and total dietary fiber contents [15].

Phytochemical analysis

Food samples (10g) were extracted withaqueous (polarity index: 9) in a soxhlet extractor for 24 hours. The extracts were concentrated using rotator evaporator (IKA), and stored at $4^{\circ} \mathrm{C}$. Phytochemicals such as total phenolic content [16] and total flavonoid content [17] were estimated and the results were expressed as $\mathrm{mg}$ gallic acid equivalents $(\mathrm{GAE}) / \mathrm{g}$ at $760 \mathrm{~nm}$ and quercetin equivalents $(\mathrm{QE}) / \mathrm{g}$ at $510 \mathrm{~nm}$, respectively.

Estimation of blood glucose level

Plasma glucose concentration was analyzed with glucose hexokinase [18] in a semi-automated biochemical analyzer (TC 3300).

Estimation of serum insulin level

Serum insulin concentration was measured with insulin ELISA kit (BIOTINA).

Calculation of Glycemic index and insulin index

After the administration of the reference or test foods blood glucose and insulin levels measured for $2 \mathrm{hrs}$ with 30min interval. Area Under Curves (AUC) for glucose and insulin (gAUC and iAUC) were calculated, based on Simpson's Rule, where fasting concentrations were used as the baseline and truncated at zero. Descriptive data are expressed as mean \pm standard error mean [14].

Insulin score IS (\%) was calculated for each test food by dividing the insulin AUC value for the test food by the insulin AUC value for glucose (reference food), and expressed as a percentage.

$$
\text { IS }(\%)=\quad \text { Area under the } 120 \mathrm{~min} \text { insulin response curve for } 1000 \mathrm{~kJ} \text { test food } * 100
$$

\subsection{Selection of subjects}

Area under the $120 \mathrm{~min}$ insulin response curve for $1000 \mathrm{~kJ}$ glucose

Four separate groups of 24 healthy adults [19], [20] age between 18- 40 years were selected. Informed consent was obtained from all of the subjects. The subjects taking prescribed medications and non-diabetic subjects those have fasting blood sugar greater than $100 \mathrm{mg} / \mathrm{dl}$ were excluded.

\subsection{Administration of test and reference food}

A fasting (12h overnight fast) venous blood sample ( $2.5 \mathrm{ml})$ of each subject was collected. The subjects were administrated with either $62.5 \mathrm{~g}(1000 \mathrm{~kJ})$ glucose in $250 \mathrm{ml}$ of water or with test food and where glucose was used as reference food. Venous blood samples $(2.5 \mathrm{ml})$ were collected at 30, 60, 90 and 120 min after the administration of glucose and test foods and dispensed into two tubes where one contained KF-Na EDTA (for the plasma glucose analysis) and the next tube without clotting agent (for serum insulin analysis). Blood samples were centrifuged at $2500 \mathrm{rpm}$ for $10 \mathrm{~min}$ and plasma, serum were separated into blood collection tubes and stored immediately at $-80^{\circ} \mathrm{C}$ for analysis.

\subsection{Ethical clearance}

The ethical clearance (J/ERC/13/43/NDR/0063) for this study was obtained from the 'Ethical Review Committee', Faculty of Medicine, University of Jaffna.

\subsection{Statistical methods and data analysis}

Glycemix index (GI) for each food was also calculated by using the same equation with the corresponding plasma glucose concentration. Glycemic and insulinemic indexes of different types of foods were analyzed by Randomized Complete Block Design (RCBD) using SAS software version 9.1. 
The results obtained from nutritional and phytochemical analysis with triplicate were subjected to analysis of variance by Complete Randomized Design (CRD). The significant difference among the extracts was tested in Least Significant Difference (LSD) at $5 \%$ level of significance using SAS software.

Linear-regression analysis was used to test the associations between glucose and insulin indexes, correlation between GI and nutritional, phytochemical content, that of between SI and nutritional, phytochemical content using SAS software version 9.1.

\section{Results}

Freshly prepared palmyrah based foods samples were tested for their energy content with bomb colorimeter and then serving weights were calculated. Since this study contained four different types palmyrah based food items, it was decided to select six subjects in a group. Their mean height and weight were $53.8( \pm 7.7) \mathrm{Kg}$ and $164.3( \pm 6.7) \mathrm{cm}$ respectively (TABLE 1$)$.

Table 1: Energy content, serving weights of different palmyrah based foods and means age, Body Mass Index (BMI) of the subjects

\begin{tabular}{|l|l|l|l|l|l|l|l|}
\hline Test foods & $\begin{array}{l}\text { Energy } \\
(\mathbf{m J} / \mathbf{k g})\end{array}$ & $\begin{array}{l}\text { Weight of 1000kJ } \\
\text { energy test food }(\mathbf{g})\end{array}$ & $\begin{array}{l}\text { Total Subjects } \\
\text { No. })\end{array}$ & $\begin{array}{l}\text { Males } \\
(\text { No. })\end{array}$ & $\begin{array}{l}\text { Female } \\
(\text { No. })\end{array}$ & $\begin{array}{l}\text { Mean Age } \\
(\text { Years })\end{array}$ & $\begin{array}{l}\text { Average BMI } \\
\left(\mathbf{k g} / \mathbf{m}^{2}\right)\end{array}$ \\
\hline Pinattu & $\begin{array}{l}13.092 \\
( \pm 0.05)\end{array}$ & 76.3 & 6 & 4 & 2 & $30( \pm 4.11)$ & $19.90( \pm 2.32)$ \\
\hline Jaggery & $\begin{array}{l}14.577 \\
( \pm 0.19)\end{array}$ & 68.6 & 6 & 5 & 1 & $33( \pm 3.30)$ & $19.46( \pm 2.4)$ \\
\hline Odiyal piitu & $\begin{array}{l}8.670 \\
( \pm 0.12)\end{array}$ & 115.3 & 6 & 4 & 2 & $25( \pm 1.86)$ & $21.04( \pm 1.77)$ \\
\hline $\begin{array}{l}\text { Pullukodiyal } \\
\text { snak }\end{array}$ & $\begin{array}{l}10.658 \\
( \pm 0.12)\end{array}$ & 93.8 & 6 & 3 & 3 & $33( \pm 7.21)$ & $19.47( \pm 1.82)$ \\
\hline
\end{tabular}

\subsection{Nutritional analysis of test foods}

Moisture content of theodiyalpittu and pullukodiyal flour snak was higher than jaggery and pinattu. Carbohydrate content of the jaggery $[57.75( \pm 6.8) \mathrm{g} / 100 \mathrm{~g}]$ was significantly higher than other test foods while there were no significant difference between the carbohydrate content of odiyalpittu and pullukodiyal flour snak). Protein contents of pullukodiyal flour snak was the highest $[3.90( \pm 0.2)]$ and it significantly higher than odiyalpittu [3.25( \pm 0.2$) \mathrm{g} / 100 \mathrm{~g}]$. There were no significant difference between fat contents of pullukodiyal flour snak $[4.11( \pm 1.3) \mathrm{g} / 100 \mathrm{~g}]$, odiyalpittu $[5.94( \pm 1.4) \mathrm{g} / 100 \mathrm{~g}]$ and very little amount of fat content found in jaggery and pinattu. Pinattu $[11.98( \pm 1.9) \mathrm{g} / 100 \mathrm{~g}]$ contained highest amount of TDF and it was significantly higher than that in odiyalpittu $[10.12( \pm 1.5) \mathrm{g} / 100 \mathrm{~g}]$, pullukodiyal flour snak $[7.87( \pm 2.7) \mathrm{g} / 100 \mathrm{~g}]$ and jaggery $[2.15( \pm 2.0) \mathrm{g} / 100 \mathrm{~g}](\mathrm{TABLE} 2)$.

\subsection{Phytochemicals analysis of test foods}

Total flavonoid and phenol contents of all the test foods significantly $(\mathrm{p}<0.05)$ different from each other. Both total flavonoid and phenol contents were highest in pinattu (TABLE 2).

Table 2: Nutrient, phytochemical contents and GI and IS of test

\begin{tabular}{|l|l|l|l|l|l|}
\hline Nutrients/ Phytochemicals & Jaggery & Pinattu & Odiyal pittu & Pullukodiyal flour snak \\
\hline \multirow{3}{*}{$\begin{array}{l}\text { Nutrients } \\
\text { (g/ serving weight ) }\end{array}$} & Moisture & $5.71( \pm 0.01)^{\mathrm{d}}$ & $12.86( \pm 0.79)^{\mathrm{c}}$ & $56.86( \pm 0.01)^{\mathrm{a}}$ & $35.02( \pm 0.53)^{\mathrm{b}}$ \\
\cline { 2 - 6 } & Carbohydrate & $57.75( \pm 6.8)^{\mathrm{a}}$ & $45.82( \pm 1.5)^{\mathrm{b}}$ & $38.66( \pm 8.4)^{\mathrm{c}}$ & $41.68( \pm 8.2)^{\mathrm{c}}$ \\
\cline { 2 - 6 } & Protein & $0.91( \pm 0.0)^{\mathrm{c}}$ & $1.80( \pm 0.2)^{\mathrm{b}}$ & $3.25( \pm 0.2)^{\mathrm{b}}$ & $3.90( \pm 0.2)^{\mathrm{a}}$ \\
\cline { 2 - 6 } & Fat & $0.03( \pm 0.0)^{\mathrm{b}}$ & $0.05( \pm 0.0)^{\mathrm{b}}$ & $5.94( \pm 1.4)^{\mathrm{a}}$ & $4.11( \pm 1.3)^{\mathrm{a}}$ \\
\cline { 2 - 6 } & Total dietary fiber & $2.15( \pm 2.0)^{\mathrm{c}}$ & $11.98( \pm 1.9)^{\mathrm{a}}$ & $10.12( \pm 1.5)^{\mathrm{b}}$ & $7.87( \pm 2.7)^{\mathrm{b}}$ \\
\cline { 2 - 7 } & Ash & $2.05( \pm 0.0)^{\mathrm{b}}$ & $3.15( \pm 0.1)^{\mathrm{a}}$ & $0.46( \pm 0.0)^{\mathrm{d}}$ & $1.24( \pm 0.0)^{\mathrm{c}}$ \\
\hline $\begin{array}{l}\text { Phytochemicals } \\
\text { (mg/serving } \\
\text { weight) }\end{array}$ & Total Phenol content & $176.5( \pm 0.03) \mathrm{b}$ & $315.6( \pm 0.02) \mathrm{a}$ & $43.7( \pm 0.01) \mathrm{d}$ & $126.0( \pm 0.01) \mathrm{c}$ \\
\cline { 2 - 6 } & $\begin{array}{l}\text { Total Flavoniod } \\
\text { content }\end{array}$ & $28.7( \pm 0.06) \mathrm{c}$ & $188.1( \pm 0.06) \mathrm{a}$ & 0.0 & $66.6( \pm 0.02) \mathrm{b}$ \\
\hline GI (\%) & 53.77 & 52.90 & 52.27 & 60.33 \\
\hline IS(\%) & 62.50 & 36.47 & 68.90 & 40.17 \\
\hline
\end{tabular}

Each value in the table is represented as mean $\pm \mathrm{SD}(\mathrm{n}=3)$. Values in the same rows followed with a different letter (a-d) are significantly different $(\mathrm{p}<0.05)$.

3.3 Fasting glucose and insulin concentrations

Fasting plasma glucose and serum insulin levels of it four different groups of subjects showed no significant difference between reference and test foods (TABLE 3).

\subsection{Relationship between BMI and fasting glucose, insulin concentrations}

Mean fasting insulin concentration of each test foods such as jaggery, pinattu, odiyalpittu and pullukodiyal flour snak was negatively correlated with mean BMI values of respective group that variability was $52,91,83$, and $13 \%$ respectively while there were significant different $(\mathrm{p}>0.05)$ between fasting insulin concentration and BMI. Likewise there were positive correlation between mean fasting glucose concentrations of groups consuming Jaggery and pullukodiyal flour snak and mean BMI values respective group, while there 
were negative correlation for mean fasting glucose concentrations of groups consuming pinattu, odiyalpittu BMI values respective group therefore coefficient determination values accounted for $2,29,1$, and $18 \%$ variability in BMI respectively and no significant different between fasting glucose concentrations and mean BMI.

\subsection{AUC of glucose and insulin after the consumption of test and reference foods}

There was a no significant different in both insulin and glucose AUCs of reference standards of all foods (TABLE 3). Although while there were significant differences between individual AUCs of both test foods and reference standards. Mean insulin AUCs of test foods were showed significant different, that of jaggery $(5340.75 \mathrm{uIU} / \mathrm{ml} / \mathrm{min})$ was showed significantly higher than other three test foods. However; Mean glucose AUC of each test foods showed not significant different $(\mathrm{p}<0.05)$.

Table 3: Glucose and insulin concentration and AUC for all the group of test and reference foods

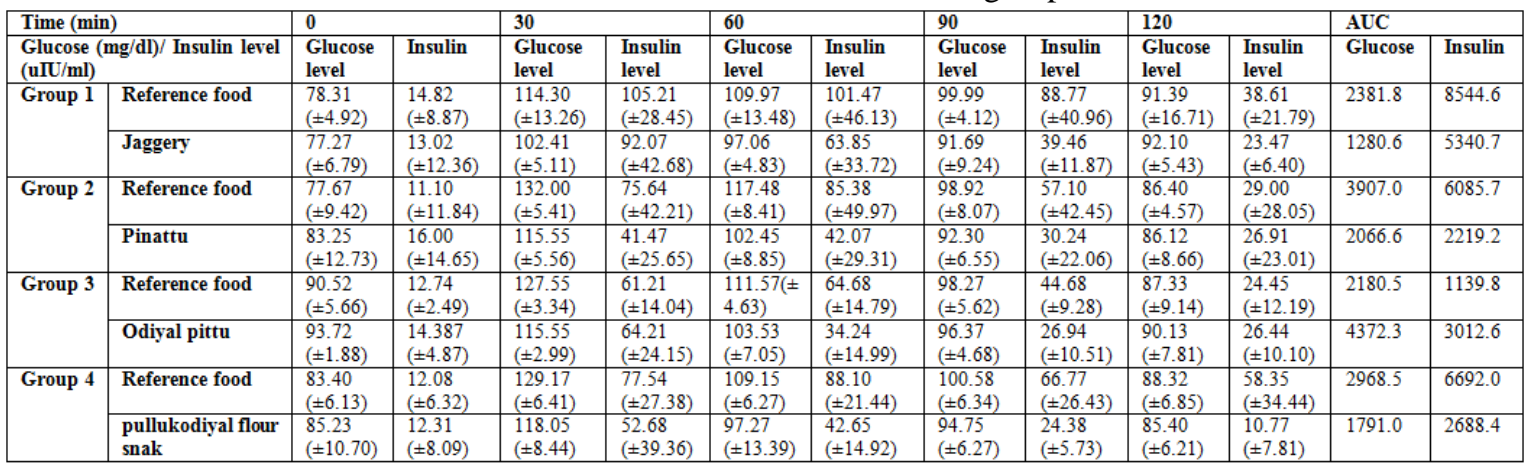

Insulin AUC values were divided by glucose AUC values which were 8.59, 1.26, 3.37 and 1.28 for Jaggery, pinattu, odiyalpittu and pullukodiyal flour respectively while there were no significant different between pinattu, odiyalpittu and pullukodiyal flour. Therefore Jaggery was a markedly insulinogenic relative to their glycemic effect (Fig: 1). Consequently jaggery was a greatest product to promote the production or release of insulin to their glycemic response followed by other palmyrah products such as odiyalpittu, pullukodiyal flour and pinattu.

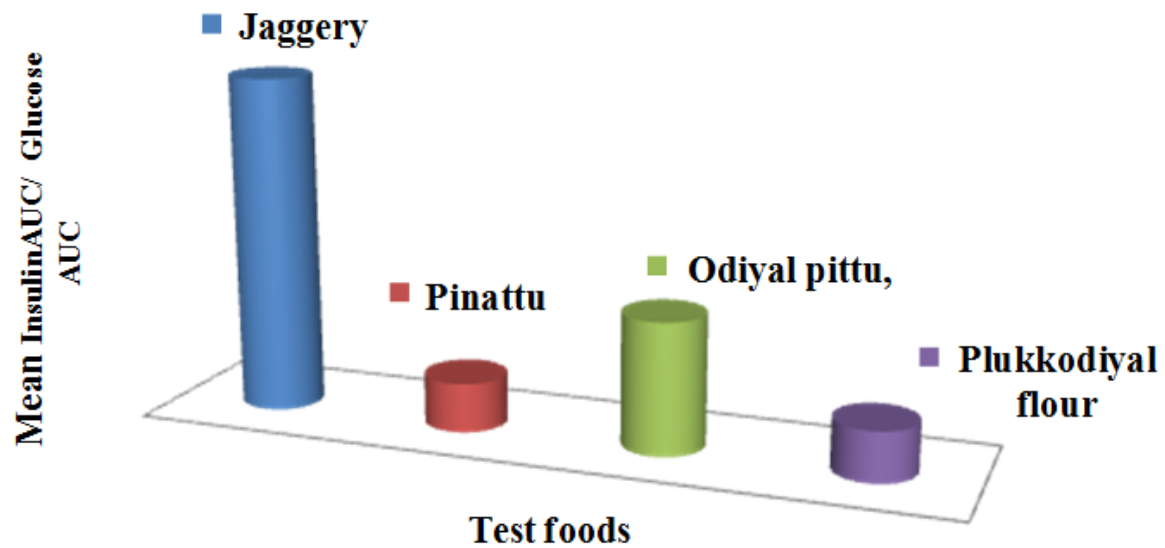

Fig 1: Ratio of insulin AUC to glucose AUC responses.

\subsection{Effects of different nutrient on GI values}

Linear-regression analysis of carbohydrate was not significant different while other nutritional factors such as fat, TDF, ash and protein showed significant different $(\mathrm{p}<0.05)$ among the test foods. Correlation coefficient values of TDF ( $\mathrm{r}=-0.02, \mathrm{p}=0.008)$, carbohydrate $(\mathrm{r}=-0.03, \mathrm{p}=0.055)$ and $\mathrm{ash}(\mathrm{r}=-0.04, \mathrm{p}=0.006)$ showed negatively correlated with GI values of test foods while positively correlated with protein $(\mathrm{r}=0.42$, $\mathrm{p}=0.007)$ and fat $(\mathrm{r}=0.04,0.003)$.

\subsection{Effects of different nutrient on IS values}

Linear-regression model showed not significant different between SI values of test foods and nutrients such as carbohydrate, TDF, protein, fat and ash. Mean IS values were negatively correlated with TDF $(\mathrm{r}=-0.18)$, protein $(\mathrm{r}=-0.02)$ and ash $(\mathrm{r}=-0.39)$ except fat $(\mathrm{r}=0.12)$ and carbohydrate $(\mathrm{r}=-0.01)$. The above same correlation pattern was found between nutritional content of composite meals and insulin response by Bao et al., 2009 [21].

\subsection{Effects of different phytochemicals on GI and IS value}


Linear-regression model was not showed significant different between GI values and phytochemical contents of test foods. There were negatively week correlation between total flavonoid $(\mathrm{r}=0.01)$, total phenol $(\mathrm{r}=0.01)$ and GI values of test food. As well there were negatively correlation between total flavonoid $(\mathrm{r}=0.65)$, phenol $(\mathrm{r}=-0.35)$ content and IS values of test foods therefore 65 and $35 \%$ of variability in IS values of test foods respectively.

\subsection{Glycemic and insulin indexes}

The raise in blood glucose level and insulin level was less than that of reference food (glucose) (TABLE 2). Among the palmyrah based products pinattu was low GI (52.90) and low IS (36.46) while jaggery (53.77) and odiyalpittu (52.27) were low GI and medium IS and both GI and IS was medium for pullukodiyal flour snak (TABLE 2).

\section{Discussion}

The glycemic index and insulin index of palmyrah foods are an important tools used in treat people with diabetes and in weight control. Food with a low GI makes full lengthier and stay satisfied longer, less likely to overeat. The GI helps to know the type of foods which are useful to control the blood glucose level. Insulin index which is less well-known index is more important than the measures of glycemic response [14]. Therefore this study on glycemic index and insulin index was under taken to measure it GI and IS of the palmyrah based edible products. Nevertheless, no studies have been carried out and reports do not available on GI and IS of palmyrah based edible products. In fact, the GI of a carbohydrate-rich food can vary greatly depending on a number of factors including the variety, origin, processing, and preparation of the food, the other nutrients that are consumed with the food and even the time of day in which the GI is measured [22].

Wolever \& Bolognesi, 1996 [23] reported that glycaemic response data obtained from a test at lunch time, after a standard breakfast, differ significantly from those obtained after an overnight fast. In various in vivo studies test food servings have been determined based on calculated data or data received from food tables and those do not resemble to the actual nutrient composition of the food product. In the present study energy of the consumed test foods were determined by using bomb colorimeter. The energy obtained from pinattu, jaggery, odiyalpittu and pullukodiyal flour snak were used for calculate the serving weight of each test foods.

Gaesser, 2007 [24] actually showed that diets with higher GLs were associated with lower BMIs. In this study there were significant correlation was found between mean fasting insulin concentrations and mean BMI values, same result was reported by Holt et al., 1997 [14] among the six groups of subjects. Jaggery and pullukodiyal flour showed positive correlation while pinattu and odiyal pittu showed negative correlation between mean fasting glucose concentration and mean BMI hence BMI was increased that pinattu and odiyalpittu decreased the mean fasting glucose concentration, this could be due to the amount of dietary fiber content of the test foods because order of the TDF content was pinattu>odiyalpittu>pullukodiyal flour > jaggery (TABLE 2).Incremental AUC is the area beneath the curve only down to fasting level. If the blood glucose level falls below the baseline, the area below fasting is ignored. Thus, the incremental AUC can never be less than zero [25]. All the test foods showed insulinogenic relative to their glycemic effect base on the ratio obtained from the insulin AUC values were divided by glucose AUC values (Figure 1). In fact, the earlier study on palmyrah pinattu as an anti-diabetic food component by Uluwaduge et al., (2007) [4] showed in insulin-dependent diabetic patients (IDDM) revealed a lower glucose response to pinattu and there was a significant reduction $(\mathrm{p}<0.01$, by $15-48 \%)$ in blood glucose concentration after a glucose challenge.

Ahmed et al., 1976 found that addition fat to carbohydrate meal enhances insulin secretion even though the plasma glucose response actually decreases and also Holt et al., 1997 [14] found no relation between the postprandial insulin response and the fiber content of a food. Whereas Albrink et al (1979) [26] found that lower insulin response in healthy subjects when consume meals that have high-fiber content than low-fiber content [27]. Palmyrah pinattu contained appropriate amount of dietary fiber. Therefore it should influence the GI and IS of palmyrah pinattu and has low GI and IS (TABLE 2). Glucose and insulin responses decreased after with meals containing soluble fibers, including pectin, Oatrim (oat fiber extract), guar gum, and methyl cellulose fibers, when compared with meals without soluble fiber (Behall et al., 2002). Morgan (1992) [28] reported that three macronutrients stimulate the release of several gut peptides, but to different degrees. Protein and fat are particularly effective in stimulating gut peptide release despite a small glucose effect. Thus, the insulin response to a carbohydrate food varies with the amount of fat, protein, or both. Palmyrah products generate lower postprandial insulin response than reference standard glucose. This response is not only due to the fiber content of products, but also due to the bioactive components such as total phenol as saponin etc. (TABLE 2) and the physical structure of palmyrah products. There were significant correlation were observed between phytochemicals and GI values of test foods.

\section{Conclusion}


This present study showed that among palmyrah based products pinattu showed low glycemic and insulin index. Specifically these products decrease postprandial insulin response compared to reference standard glucose. In other words, less insulin is required for regulation of postprandial plasma glucose concentrations in healthy subjects after intake of all tested palmyrah food products than glucose. High plasma insulin has been shown to be an independent risk factor for coronary heart disease. Therefore palmyrah based food products could be used in order to develop new value added foods, which could have more beneficial health properties regarding glucose and insulin metabolism.

\section{Acknowledgements}

The authors like to thank Palmyrah Research Institute, Palmyrah Development Board, Jaffna, Sri Lanka and Department of Biochemistry Faculty of Medicine, University of Jaffna, for providing the necessary facilities.

\section{References}

[1]. P.C.Vengaiah, B. Vijaya kumara, G.N. Murthy and K.R.. Prasad, Physico-Chemical Properties of Palmyrah fruit Pulp (Borassus flabellifer L), J Nutr Food Sci, 2015, 5:5.

[2]. K. Theivendirarajah , Palmyrah Palm, A Monograph, K. Theivendirarajah, Roxanne Crescent, scarborough, ntario, Canada, 2008, 1, 27-53.

[3]. S. Mahendran, K.Balasubramaniam, K. Sivaganeshan, Mechanical extraction of palmyrah fruit pulp. Bioprocess Engineering 1993, $8(5), 301-302$

[4]. I. Uluwaduge, A. Perera, E. jansz, and I. A. Thabrew, Pilot study on palmyrah pinattu (dried fruit pulp) as an anti-diabetic food component, Int. J. Biol. Chem. Sci. 2007, 1(3): 250-254.

[5]. M. Paschapur, S.Patil, M. B., Kumar R. and S.R. Patil, Evaluation of anti-inflammatory activity of ethanolic extract of Borassus flabellifer L. male flowers (inflorescences) in experimental animals, Journal of Medicinal Plants Research 2009, 3(2), 049-054.

[6]. P. G. Jamkhande, V. A. Suryawanshi, A. S. Wattamwar and S. R. Barde, In vitro anthelmintic efficacy of Borassus flabellifer Linn. (Palmae) against Pheretimaposthuma, Asian Pac J Trop Dis, 2014; 4: S199-S203

[7]. M. Yoshikawa, F. Xu T. Morikawa, Y. Pongpiriyadacha, S. Nakamura Asao. Medicinal flowers. XII (1) New spirostane-type steroid saponins with antidiabetogenic activity from Borassusflabellifer. Chem. Pharm. Bull., 2007, 55: 308-316.

[8]. L. Révész, P. Hiestand La, L.Vecchia, R. Naef, HU. Naegeli, L. Oberer. Isolation and synthesis of a novel immunosuppressive alpha-substituted dammarane from the flour of the Palmyrah palm (Borassus flabellifer). Bioorg. Med. Chem. Lett. 1999, 9: 15211526.

[9]. K. Arunachalam, S. Saravanan and T. Parimelazhagan, Nutritional Analysis and Antioxidant Activity of Palmyrah (Borassusflabellifer L.) Seed Embryo for Potential Use as Food Source, Food Sci. Biotechnol, 2011. 20(1): 143-149.

[10]. P.C. Vijayakumari1, Vengaiah and P. Kiranmayi, Physicochemical and functional characteristics of powder prepared from palmyra fruit pulp (Borassus flabelliferL.).Int.J.Curr. Microbiol. App. Sci, 2014, 3(9) 352-356.

[11]. ER. Jansz, NT. Wickremasekara and KAV. Sumuduni, A Review of the Chemistry and Biochemistry of seed shoot flour and fruit pulp of the Palmyrah palm (Borassus flabelliferL.). Journal of National Science Foundation of Sri Lanka. 2002; 30(1\&2): 61-87.

[12]. ZX. Lu, KZ. Walker, JG Muir, K.O’Dea, Arabinoxylanfibre improves me tabolic control in people with Type II diabetes. Eur J ClinNutr, 2004; 58: 621-628.

[13]. M. Chandalia, A. Garg, D. Lutjohann von K. Bergmann, SM. Grundy, LJ. Brinkley,Beneficial effects of high dietary fiber intake in patientswith type 2 diabetes mellitus. N Engl J Med, 2000; 342: 1392-1398.

[14]. SH, Holt, JC, Miller, P. Petocz, An insulin index of foods: the insulin demand generated by 1000-kJ portions of common foods. Am J ClinNutr., 1997; 66:1264-76.

[15]. AOAC International (2002). AOAC Official Methods of Analysis. (2002), 17th Edition, ASSOCIATION OF OFFICIAL ANALYTICAL CHEMISTS Washington, USA.

[16]. S. Maurya and D. Singh, Quantitative Analysis of Total Phenolic Content in Adhatodavasica Needs. Extracts International Journal of PharmTech Research. 2010, 4: 2403-2406.

[17]. AA. Ordonez L, JD. Gomez, MA. Vattuone and MI .Isla. Antioxidant activities of Sechiumedule (Jacq.) Swart extracts, Food Chem. 2006, 97:452-458.

[18]. TMS. Wolever, DJA. Jenkins, AL. Jenkins, RG. Josserg, The Glycemic Index: Methodology and Clinical Implications. The American Journal of Clinical Nutrition, 1991, 846- 854.

[19]. TM. Wolever, JC. Brand-Miller, J. Abernethy, A. Astrup, F. Atkinson, M.Axelsen, I. Björck, F Brighenti, R Brown, A Brynes, MC Casiraghi, M Cazaubiel, L Dahlqvist, E Delport, GS Denyer, D Erba, G Frost, Y Granfeldt, S Hampton, VA Hart, KA Hätönen, CJ Henry, S Hertzler, S Hull, J Jerling, KL Johnston, H Lightowler, N Mann, L Morgan, LN Panlasigui, C Pelkman, T Perry, AF Pfeiffer, M Pieters, D Dan Ramdath, RT Ramsingh, SD Robert, C Robinson, E Sarkkinen, F Scazzina, DC B Sison, Sloth, J Staniforth, N Tapola, LM Valsta, I Verkooijen, MO Weickert, Weseler AR, P Wilkie, J Zhang, Measuring the glycemic index of foods: inter laboratory study, Am J Clin Nutr 2008, 87:247S-57S.

[20]. M., Pieters and J., C Jerling,. Measuring the glycaemic index - consensus and issues of debate, South African Journal of Clinical Nurition, 2005, 18:03.

[21]. J. Bao, V. Jong, F.a Atkinson, P. Petocz, and J. C B.Miller Food insulin index: physiologic basis for predicting insulin demand evoked by composite meals. Am J ClinNutr 2009; 90:986-92.

[22]. Pi-Sunyer, FX. Glycemic index and disease. Am J ClinNutr. 2002; 76(suppl):290S-298S

[23]. TMS. Wolever \& C Bolognesi, Time of day influences relative glycaemic effect of foods. Nutrition Research 1996,16, 381-384.

[24]. GA.Gaesser, Carbohydrate quantity and quality in relation to body mass index. J Am Diet Assoc. 2007; 107:1768-80.

[25]. Wolever TMS. Carbohydrate and the regulation of blood glucose and metabolism. Nutr Rev. 2003, 61:S40-S46.

[26]. MJ. Albrink Newman T \& Davidson PC: Effect of high- and low- fiber diets on plasma lipids and insulin. Am. J. Clin. Nutr. 1979, $32,1486 \pm 1491$.

[27]. DJ. Jenkins, TM. Wolever, AL. Jenkins, Low glycemic response to traditionally processed wheat and rye products: bulgur and pumpernickel bread, Am J ClinNutr 1986, 43:516-20.

[28]. L. Morgan, Insulin secretion and the entero-insular axis. In: Rau PR, ed. Nutrient regulation of insulin secretion. London: Portland Press Ltd. 1992, 1-22. 